Indexed by:

Asinta

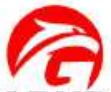

GARUDA

Crossref

crossmark

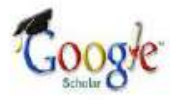

Dimensions

Oone

Manuscripts screening

tools:

turniting)

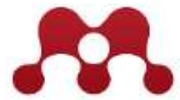

MENDELEY

G grammarly

\title{
PENGARUH APLIKASI MATERIAL FASADE BANGUNAN TERHADAP UPAYA KONSERVASI ENERGI DENGAN PENDEKATAN EVALUASI DESAIN BERBASIS BIM (BUILDING INFORMATION MODELING)
}

\section{Petra Christian}

Program Studi Teknik

Arsitektur, Universitas Prisma,

Kota Manado, Indonesia

Jl. Pomurow No. 133 Tikala Baru Kota

manado
Steven Richard Kamurahan

Program Studi Teknik Arsitektur, Universitas Prisma, Kota Manado, Indonesia

Jl. Pomurow No. 133 Tikala Baru Kota manado

Key words:

Facade Materials, Energy Evaluation, BIM Archicad

Doi:

10.17509/jaz.v4i1.30181

Cite article:

Christian, P., dan Kamurahan, S. R. (2021). Pengaruh Aplikasi Material Fasade Bangunan Terhadap Upaya Konservasi Energi dengan Pendekatan Evaluasi Desain Berbasis BIM ( Building Information Modeling ). Jurnal Arsitektur Zonasi, 4(1), 73-83. https://doi.org/doi.org/10.17509/jaz.v4i1.30181

Akses online:

untuk naskah lengkap tersedia di: https://ejournal.upi.edu/index.php/jaz/issue/archive 
http://ejournal.upi.edu/index.php/jaz - e-mail:_jurnal_zonasi@upi.edu doi.org/10.17509/jaz.v4i1.30181

\section{PENGARUH APLIKASI MATERIAL FASADE BANGUNAN TERHADAP UPAYA KONSERVASI ENERGI DENGAN PENDEKATAN EVALUASI DESAIN BERBASIS BIM (BUILDING INFORMATION MODELING)}

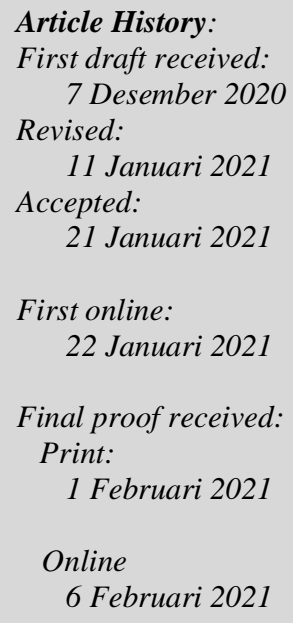

Jurnal Arsitektur ZONASI is indexed and listed in several databases:

SINTA 4 (Arjuna)

GARUDA (Garda Rujukan Digital)

Google Scholar

Dimensions

oneSearch

BASE

Member:
Crossref
RJI
APTARI
FJA (Forum Jurna Arsitektur)
IAI
AJPKM

\author{
Petra Christian ${ }^{1}$ \\ Steven Richard Kamurahan ${ }^{2}$ \\ 1,2 Program Studi Teknik Arsitektur Universitas Prisma, Kota Manado, Indonesia \\ Jl. Pomurow No. 133 Tikala Baru Kota Manado \\ Email : petrach12@gmail.com \\ kamurahan13@gmail.com
}

Abstract: The use of artificial air conditioning $(A C)$ and building mechanical devices today generally has a large portion of the use of electrical energy in addition to lighting needs. This encourages the importance of careful design consideration and selection of building materials, so that in addition to saving operational costs, it can also contribute to energy conservation efforts. With a building design approach based on BIM (Building Information Modeling), buildings can be designed in a virtual multidimensional way based on their components and material specifications and can simulate their material characteristics, one of which is the ability of the material to insulate heat. The higher the ability of the facade material to withstand heat, the less electrical energy is used in the building for artificial cooling (AC) units. This research case study is the Prisma University campus building in Manado City which was completed in 2018 and entered the operational period with the main function of accommodating lecture activities and supporting administrative activities. The method used in this research is building three-dimensional (3D) modeling and simulation that focuses on evaluating energy usage with certain performance criteria, namely through the Energy Evaluation feature on the Archicad R.24 software.

Keywords : Facade Materials, Energy Evaluation, BIM Archicad

\begin{abstract}
Abstrak :Pengunaan penghawaan udara buatan (AC) dan perangkat mekanikal bangunan saat ini umumnya memiliki porsi yang besar pengunaan energi listrik selain untuk kebutuhan pencahayaan. Hal ini mendorong pentingnya pertimbangan desain serta pemilihan material bangunan secara seksama, sehingga selain dapat menghemat biaya operasional juga dapat memberi sumbangsih dalam upaya konservasi energi. Dengan pendekatan perancangan bangunan berbasis BIM (Building Information Modeling), bangunan dapat didesain secara virtual multidimensi berdasarkan komponen dan spesifikasi materialnya serta dapat disimulasikan karakteristik materialnya, salah satunya dalam hal kemampuan material untuk mengisolasi panas. Semakin tinggi kemampuan material fasade menahan panas, maka semakin sedikit energi lisrik yang dipakai pada bangunan untuk unit pendinginan buatan (AC). Studi kasus penelitian ini adalah gedung kampus Universitas Prisma di Kota Manado yang selesai dibangun tahun 2018 dan memasuki masa operasional dengan fungsi utama mewadahi aktivitas perkuliahan serta aktivitas administrasi penunjangnya. Metode yang akan digunakan dalam penelitian ini adalah permodelan dan simulasi tiga dimensi (3D) bangunan yang difokuskan pada evaluasi pengunaan energi dengan kriteria performa tertentu, yakni melalui fitur Evaluation Energy pada sofware Archicad R.24.
\end{abstract}

Kata Kunci : Material Fasade, Evaluasi Energi, BIM Archicad

\section{Pendahuluan}

Dengan kondisi iklim yang panas, bangunan dituntut tetap nyaman dalam pengunaanya. Fasade bangunan ibarat selubung atau pakaian pada bangunan yang memiliki peran penting dalam menangkal sengatan matahari, selain bidang atap. Pada bangunan berlantai banyak luas permukaan bidang dinding jelas 
akan lebih luas dari permukaan bidang atap, di mana hal ini akan menetukan seberapa besar panas akan terinduksi ke dalam bangunan. Selain upaya konservasi energi dari sudut kemampuan material fasade mengisolasi panas, setiap material memiliki tingkat konsumsi energi baik dalam proses produksinya maupun pada performa fungsinya, semakin rendah energi yang digunakan atau ditimbulkan dari pengunaannya, maka semakin baik material tersebut.

Permasalahan di atas memberi gambaran perlunya solusi berupa saran atau rekomendasi dalam pemilihan material fasade bangunan dengan pertimbangan pada upaya konservasi energi termasuk penghematan biaya operasional yang perlu disediakan. Dengan mengetahui implikasi pemilihan material fasade dengan konsekuensi pada tingkat konsumsi energi listrik yang dibutuhkan untuk penghawaan udara buatan,maka pemilihan material menjadi hal penting yang perlu dipertimbangkan dalam rangka menghemat biaya operasional bangunan serta turut berpartisipasi dalam upaya konservasi energi.

Urgensi dari penelitian ini adalah pada meningkatnya fenomena pemanasan global dan borosnya pengunaan energi listrik yang masih bergantung bersumber dari energi tak terbarukan, terutama dari bangunanbangunan yang operasionalnya membutuhkan pasokan energi listrik yang besar terutama untuk pengawaan udara buatan (AC). Hal ini akan berdampak pada habisnya sumberdaya energi tersebut dikemudian hari, jika di tambah dengan munculnya bangunan -bangunan baru sejenisnya yang tidak mempertimbangkan upaya konservasi energi.

Sebagai salah satu gedung baru yang mulai beroperasi tahun 2018, gedung kampus Universitas Prisma di Kota Manado didesain dengan tampilan fasade tertutup dan didominansi oleh pengunaan material kaca dan ACP (allumunium composite panel) serta pengunaan penghawaan udara buatan pada sebagian besar ruangannya.
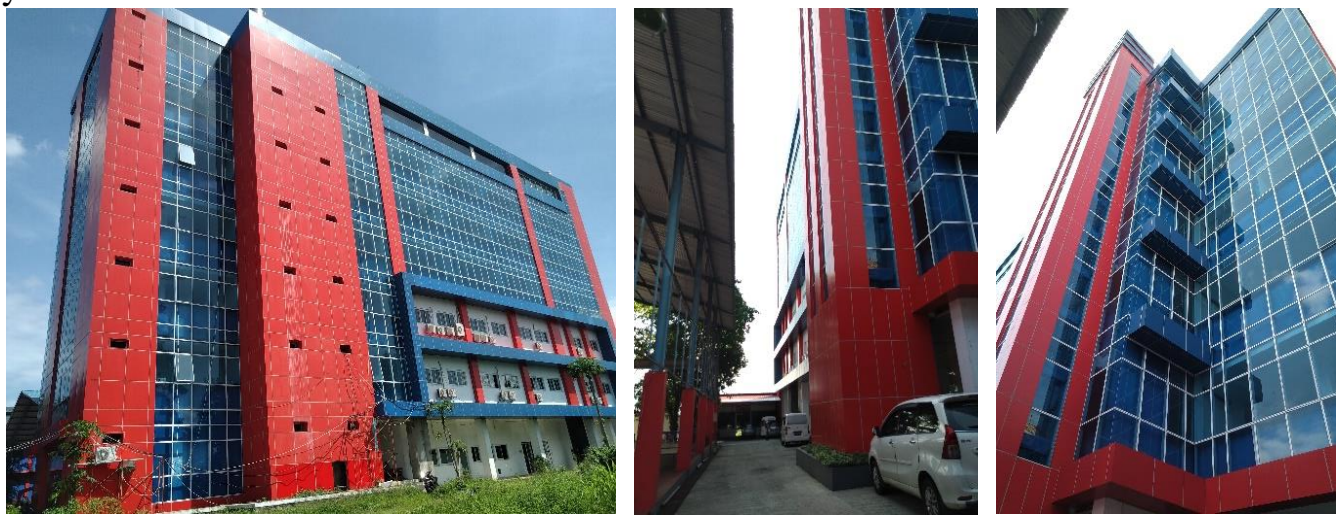

Gambar 1. Gedung Kampus Universitas Prisma di Kota Manado (sumber. Dokumetasi peneliti, 2020)

Berdasarkan rincian jumlah dan spesifikasi unit perangkat penghawaan udara buatan (AC) eksisting di gedung kampus Universitas Prisma yakni sebanyak 30 unit AC split 2 PK dan 12 unit AC standing 5 PK. Dengan estimasi pengunaan daya rata-rata perbulan dengan asumsi operasional 8 jam per hari dan 25 hari per bulan dari tabel dibawah dapat diperoleh gambaran pengunaan energi listrik dari pengunaan perangkat penghawaan udara rata-rata dalam satu tahun, yakni $225.216 \mathrm{KWh}-281.520 \mathrm{KWh}$ atau sekitar 225,21 - 281,52 MWh.

Tabel 1. Pengunaan energi listrik untuk penghawaan buatan (AC)

\begin{tabular}{|l|c|c|c|c|c|}
\hline Perangkat AC & $\begin{array}{c}\text { Daya Listrik } \\
(\mathrm{W})\end{array}$ & $\begin{array}{c}\text { Jumlah } \\
\text { Unit }\end{array}$ & $\begin{array}{c}\text { Konsumsi } \\
\text { daya rata-rata } \\
\text { per unit } \\
(\mathrm{KWh})\end{array}$ & $\begin{array}{c}\text { Jumlah } \\
\text { Konsumsi daya } \\
(100 \%) \mathrm{KWh}\end{array}$ & $\begin{array}{c}\text { Jumlah } \\
\text { Konsumsi } \\
\text { daya }(80 \%) \\
\text { KWh }\end{array}$ \\
\hline $\begin{array}{l}\text { AC 2 PK Panasonic } \\
\text { Type CS-PN18SKP }\end{array}$ & 1.990 & 30 & 4.776 & 143.280 & 114.624 \\
\hline $\begin{array}{l}\text { AC 5 PK Panasonic } \\
\text { Type CS-J45FFP8 }\end{array}$ & 4.800 & 12 & 11.520 & 138.240 & 110.592 \\
\hline \multicolumn{2}{|r|}{} & Total & 281.520 & 225.216 \\
\hline
\end{tabular}

(sumber. Perhitungan sendiri, 2020)

Pengaruh desain bangunan pada massa operasionalnya salah satunya akan ditentukan pada pemilihan meterialnya. Hal ini dipengaruhi dari kemapuan material yang dipilih dalam ketahanannya pada faktor iklim yang diterima oleh suatu bangunan. Pada hakekatnya tujuan suatu bangunan di desain kemudian dibangun 
serta dimanfaatkan adalah sebagai tempat untuk berlindung sekaligus tempat beraktivitas bagi manusia. (Rosman, 2007).

Pemilihan material bangunan ditentukan oleh banyak faktor (Allen, 2015) yakni: ketersedian material tersebut di pasaran, daya tahan material, tujuan atau fungsi bangunan, teknologi dan kemampuan pertukangan dalam aplikasinya, efisisensi dan harga material. Tak dapat dipungkiri pemilihan material juga dipengaruhi oleh karakter atau citra yang dikesankan dari material tersebut. Dewasa ini pemilihan material dipengaruhi pula oleh kesan moderen atau kekinian suatu material, sebagai contoh pengunaan material kaca, baja, dan ACP (Alumunium composite panel) pada bangunan-bangunan terutama yang berlantai banyak. (Sebestyen, 2003).

Aspek yang berpengaruh pada terjadinya kenyamanan termal(Kusumawati, 2015) adalah: a) Radiasi sinar matahari yang menghasilkan cahaya dan panas mempengaruhi persyaratan beban pendinginan dan desain pencahayan bangunan. Hal ini dipengaruhi oleh tata letak bangunan dan material yang digunakan pada selubung bangunan; b) Suhu udara dan kelembaban relative tinggi menjadi alasan untuk menggunakan AC guna mencapai kenyamanan manusia dan lingkungan dalam ruangan yang diinginkan; c) Kelembaban relatif memiliki dampak yang besar terhadap lingkungan dalam ruangan dan kenyamanan termal. Sebagai salah satu faktor penentu dari sisi pengunaan material bangunan, Kaca yang digunakan sebagai material fasade bangunan memiliki pengaruh yang besar, dimana semakin tebal dan gelap warna kaca semakin rendah angka solar factor kaca, juga makin kecil penerimaan radiasi panas matahari, sebaliknya semakin tipis dan cerah warna kaca penerimaan panas yang masuk kedalam bangunan.

Untuk menujang operasional bangunan yang nyaman diperlukan dukungan perangkat pelayanan bangunan yang didesain seefisien mungkin, sehingga pengunaan energi dalam pengoperasian bangunan dapat menekan pengeluaran biaya. (Tymkow ,2013) Pengunaan energi yang berkaitan dengan material bangu nan dibagi dalam dua fase, yakni pada proses produksi dan konstruksi dan fase operasional. Pada penelitian ini akan lebih berfokus pada fase yang kedua, yakni pada fase operasionalnya, dimana akan mengambil studi kasus pada bangunan yang sedang dipakai. Penggunaan energi pada fase operasional akan berfokus pada beban pendinginan udara buatan (AC) yang memanfaatkan energi listrik sebagai sumbernya. Pengunaan energi listrik menjadi sumber utama dalam sistim pendinginan buatan atau air conditioner (AC). Dalam kaitan penelitian ini akan dihitung beban pengkondisian udara berdasarkan pemakaian normal pada ruang-ruang yang paling sering digunakan, dengan memonitor suhu ruangan ideal antara $20-28{ }^{\circ} \mathrm{C}$.

Adanya teknologi yang mampu mengsimulasikan pengunaan energi pada desain bangunan berbasis informasi komponen model bangunan atau Building Information Modeling (BIM) akan membantu penilaian pengunaan energi pada pengaplikasian material tertentu pada bangunan yang disimulasikan lewat virtual model. (Chae, 2017) Penerapan BIM sebenarnya mencakup aspek yang lebih konferhensif dari seluruh proses yang berkaitan dengan bangunan, mulai dari tahapan perencanaan, pembangunan, opersional hingga pemusnahan bangunan ketika sudah tidak lagi digunakan. (Sacks, 2018). Dalam penelitian ini penerapan BIM akan lebih berfokus pada evaluasi kinerja bangunan pada fase operasional, dengan mengsimulasikan kembali bangunan tersebut dengan virtual model yang dibuat berdasarkan as-built drawing dari bangunan yang menjadi objek kasus.

Ada beberapa berapa aspek yang dapat disimulasikan dengan pendekatan BIM yakni diantaranya : Visualisasi estetika arsitektur, struktur dan konstruksi, Suhu dan kesamaaan thermal, Pengunaan dan konservasi energi (Chae, 2017). Untuk penelitian ini simulasi akan berfokus pada pengunaan dan konservasi energi dengan memanfatkan sofware lisensi yang mendukung BIM, yakni Archicad Versi 24. Archicad sebagai salah satu pelopor software BIM merupakan perangkat lunak yang dirancanag untuk mengintegrasikan permodelan dengan fitur informasi model tersebut, baik dimensi, jenis material, spesifikasi hingga harga dan produsennya. (MacKinzie, 2015). Selain berfokus pada permodelaan dan informasi bangunan archicad juga memiliki fitur simulasi dinamis permodelan yakni evaluasi energi yang didukung ecodesigner star, serta engine kalkulasi StruSoft's VIP-Energy (Graphisoft, 2014). Dimana tahap evaluasi energi ini akan mengacu pada beberapa kriteria yang disediakan fitur software tersebut.

Sebagai pembanding tingkat pengaruh pengunaan energi, digunakan indeks intensitas energi dalam panduan penghematan energi berdasarkan Peraturan Menteri Energi dan Sumber daya Mineral nomer 13 tahun 2012 tentang penghematan pemakaian energi listrik yakni dibawah $195 \mathrm{kWh} / \mathrm{M}^{2}$ (USAID Indonesia, 2014). Selanjutnya untuk mengetahui potensi penghematan energi yang dapat diterapkan pada sebuah ruangan yang tidak masuk kategori efisien dalam menggunakan listrik, maka selisih nilai IKE hasil perhitungan dengan nilai IKE standar terlebih dahulu harus dihitung. Untuk menghitung peluang penghematan yang dapat diterapkan pada sebuah ruangan dapat digunakan persamaan (Mukhlis, 2011) berikut : 
Dari hasil permodelan yang akan dibuat serta kalkulasi evaluasi energinya, diharapkan pada objek gedung yang diteliti dapat diperoleh gambaran pengaruh desain fasade dalam pengunaan energi, apakah masih cukup efisien atau boros.

\section{Metode Penelitian}

Untuk metode yang dipakai pada penelitian ini adalah metode survei dengan pengolahan data deskriptif kuantitatif dan kualitatif. Teknik Pengumpulan Data dalam penelitian ini adalah dengan mengumpulkan : (1) Data primer yaitu suatu metode pengumpulan data yang bersifat kombinasi antara metode observasi, pengukuran dan pembuatan model virtual 3D bangunan. Untuk jenis data primer dan sumbernya yang diperlukan adalah : Data terkaiat model 3D bangunan yang akan diteliti; Spesifikasi teknis dan rincian material fasade yang digunakan; Data pengukuran suhu ruangan, konsumsi energi dan spesifikasi alat pengkodisian udara yang digunakan pada sample ruangan yang di teliti; dan data penunjang lainnya, baik dalam bentuk informasi, foto (gambar kondisi) dan sebagainya. (2) Data Sekunder yaitu data yang dapat diperoleh melalui teksbook/atau secara institusional, seperti : standart, koefisien dan data teknis terkait material yang dipakai dari katalog pabrik dan sejenisnya (properti fisik); Manual book software BIM Archicad dan EcoDesainer serta literatur terkait lainnya.

Teknik Analisis dan pengolahan data yang digunakan dalam penelitian ini adalah teknik analisis dinamis dengan perangkat EcoDesigner dari Archicad R.24, melalui tiga langkah, yakni: (1) Input data dengan menentukan properti fisik selubung bangunan yang telah dimodelkan menggunakan nilai default (yang ditetapkan untuk berbagai jenis bagian bangunan) maupun data spesifik, menyiapkan lokasi, data cuaca, jenis bangunan, dan sistem penghawaan udara buatan (AC) dari objek gedung yang diteliti; (2) Evaluasi energi melalui perangkat EcoDesigner, yang secara teritegrasi meneruskan data ke mesin kalkulasi VIP-Energy StruSoft , untuk di analisis secara dinamis; (3) Hasil analisis berupa lembar laporan dalam format PDF dan Ms. Excel yang menunjukkan hasil evaluasi selimut atau fasade bangunan, konsumsi energi dan nilai biaya, jejak karbon dan neraca energi bulanan.

\section{Hasil dan Pembahasan}

\subsection{Modeling bangunan}

Untuk melakukan kalkulasi evaluasi energi mengunakan fitur EcoDesigner, terlebih dahulu gedung yang menjadi objek penelitian harus dimodelkan kembali secara virtual dengan dengan perangkat yang telah ditentukan. Data fisik objek yang akan dimodelkan diambil melalui pengukuran dan obesevasi lapangan secara teliti dengan tujuan model yang dihasilkan mendekati wujud dan spesifikasi yang sebenarnya. Berikut adalah hasil permodelan kembali objek penelitian mengunakan sofware Archicad v.24.

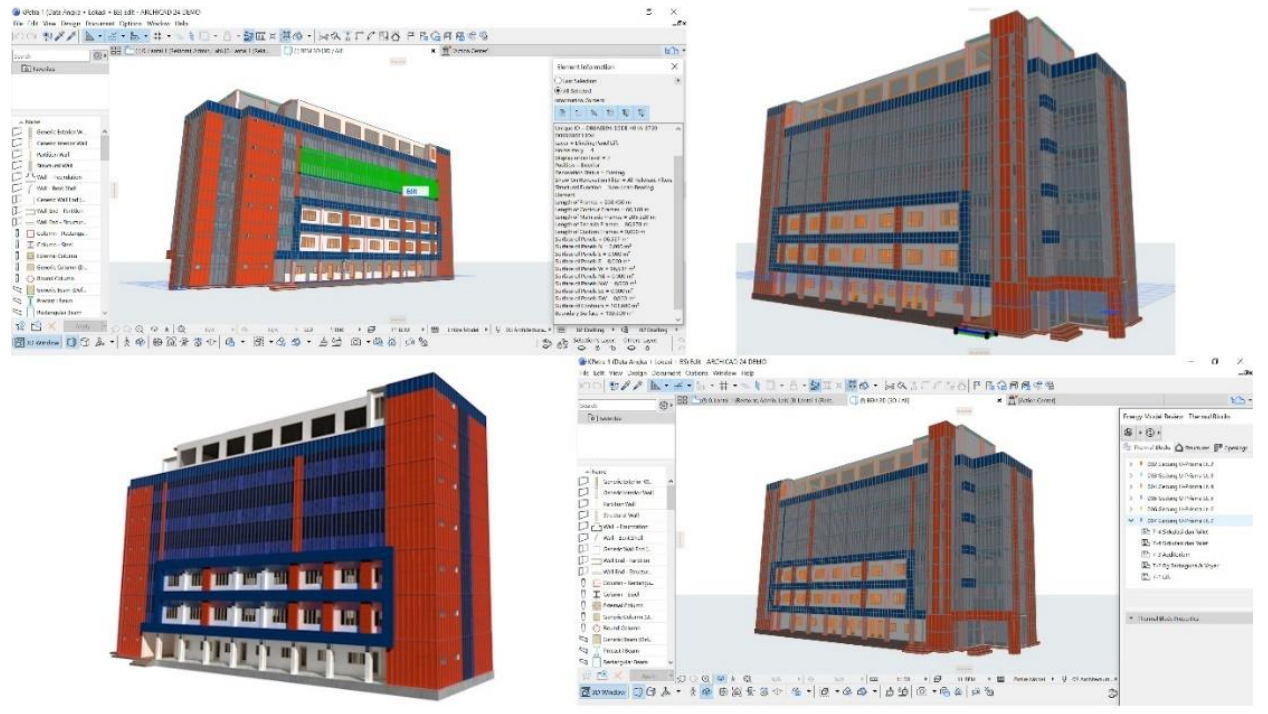

Gambar 2. Permodelan kembali Gedung Kampus Universitas Prisma dengan Archicad V.24 Sumber. Pengukuran dan modeling, 2020 
Hasil permodelan ulang gedung universitas prisma yang terdiri dari 7 lantai ini telah mengkalkulasi beberapa data atribut utama yakni :

Tabel 2. Data dan informasi model bangunan

\begin{tabular}{|l|r|l|}
\hline \multicolumn{1}{|c|}{ Atribut data/informasi model } & \multicolumn{1}{c|}{ Besaran } & Satuan \\
\hline Lokasi bangunan & Kota Manado & \\
\hline Latitude & $1^{\circ} 28^{\prime} 28^{\prime \prime} \mathrm{LU}$ & \\
\hline Longitude & $124^{\circ} 51^{\prime} 21^{\prime \prime} \mathrm{BT}$ & \\
\hline Altitude (dari muka air laut) & 53 & $\mathrm{~m}$ \\
\hline Sumber data iklim & Strusoft server & \\
\hline Luas keseluruhan bangunan & 3261,00 & $\mathrm{~m}^{2}$ \\
\hline Luas efektif bangunan & 3159,00 & $\mathrm{~m}^{2}$ \\
\hline Luas bidang fasade luar & 5468,00 & $\mathrm{~m}^{2}$ \\
\hline Volume ruangan & $10.999,00$ & $\mathrm{~m}^{3}$ \\
\hline Rasio Bukaan/Kaca & 20,95 & $\%$ \\
\hline
\end{tabular}

\subsection{Evaluasi energi dengan fitur EcoDesigner}

Sesuai dengan tujuan penelitan yakni mengetahui pengaruh aplikasi material fasade pada gedung kampus Universitas Prisma di Kota manado, termasuk seberapa besar pengunaan energi dalam hal ini listrik dalam operasional bangunannya, maka hasil permodelan bangunan berikut data dan informasi yang telah dibuat selanjutnya di simulasikan secara virtual dalam perangkat lunak yang telah dipilih. Perangkat lunak yang digunakan adalah fitur EcoDesigner yang teritegrasi dalam Archicad v. 24. Dalam melakukan simulasi evaluasi energi digunakan beberapa parameter dan kriteria yang meliputi:

\section{a. Data dan informasi lingkungan fisik}

Lokasi Bangunan berada di Jl. Pomurow Tikala Baru Kota Manado, dengan kondisi lingkungan sekitarnya tanah kosong dan beberapa bangunan serta perkerasan. Untuk kondisi tanah sekitar merupakan tanah liat dengan konduktifitas termal 0,5W/mK; kepadatan $1800 \mathrm{~kg} / \mathrm{m}^{3}$ dan kapasitas panas $1000 \mathrm{~J} / \mathrm{kgK}$. Lingkungan yang diperkeras oleh paving diasumsikanmemiliki nilai kemampuan refleksi sebesar $30 \%$.

Untuk posisi gedung yang terproktesi sebagian dengan bangunan atau unsur vegetasi adalah di sisi barat, barat daya dan barat laut. Dari sisi yang terproteksi dari sinar matahari melalui pembayangan bangunan dan vegetasi disekitarnya dengan asumsi pembayangannya rendah karena objek bangunan lebih tinggi dari semua bangunan dan elemen alami di sekitarnya. Berikut gambar tangkapan layar untuk data dan informasi fisik lingkungan yang digunakan dalam simulasi evaluasi energi ini.

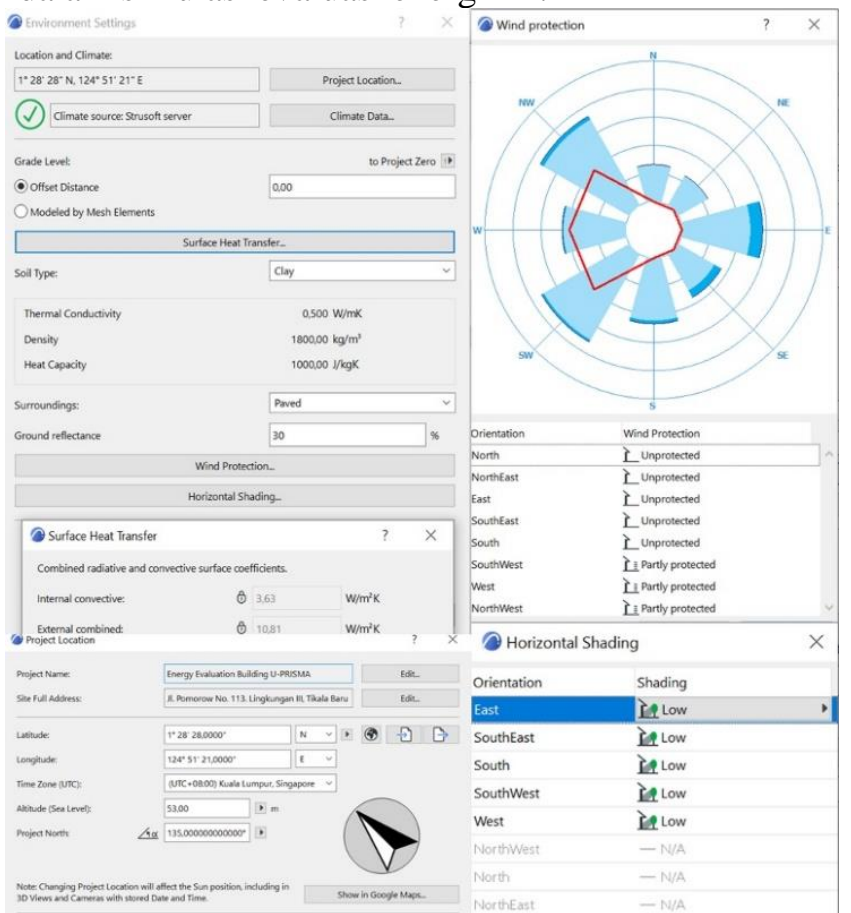

Gambar 3. Data input untuk aspek lingkungan fisik pada fitur EcoDesigner Sumber. Simulasi, 2020 


\section{b. Data dan Informasi Iklim}

Untuk data dan informasi terkait iklim mengunakan data tersedia dalam aplikasi melalui strusoft server berupa data rekaman rata-rata tahunan yakni untuk temperatur udara sebesar $27,39{ }^{\circ} \mathrm{C}$; kelembaban relatif $72,53 \%$; radiasi matahari sebesar $457,77 \mathrm{Wh} / \mathrm{m}^{2}$ dan kecepatan angin sebesar $3,28 \mathrm{~m} / \mathrm{s}$. Berikut gambar tangkapan layar untuk data dan informasi iklim yang digunakan dalam simulasi evaluasi energi ini.

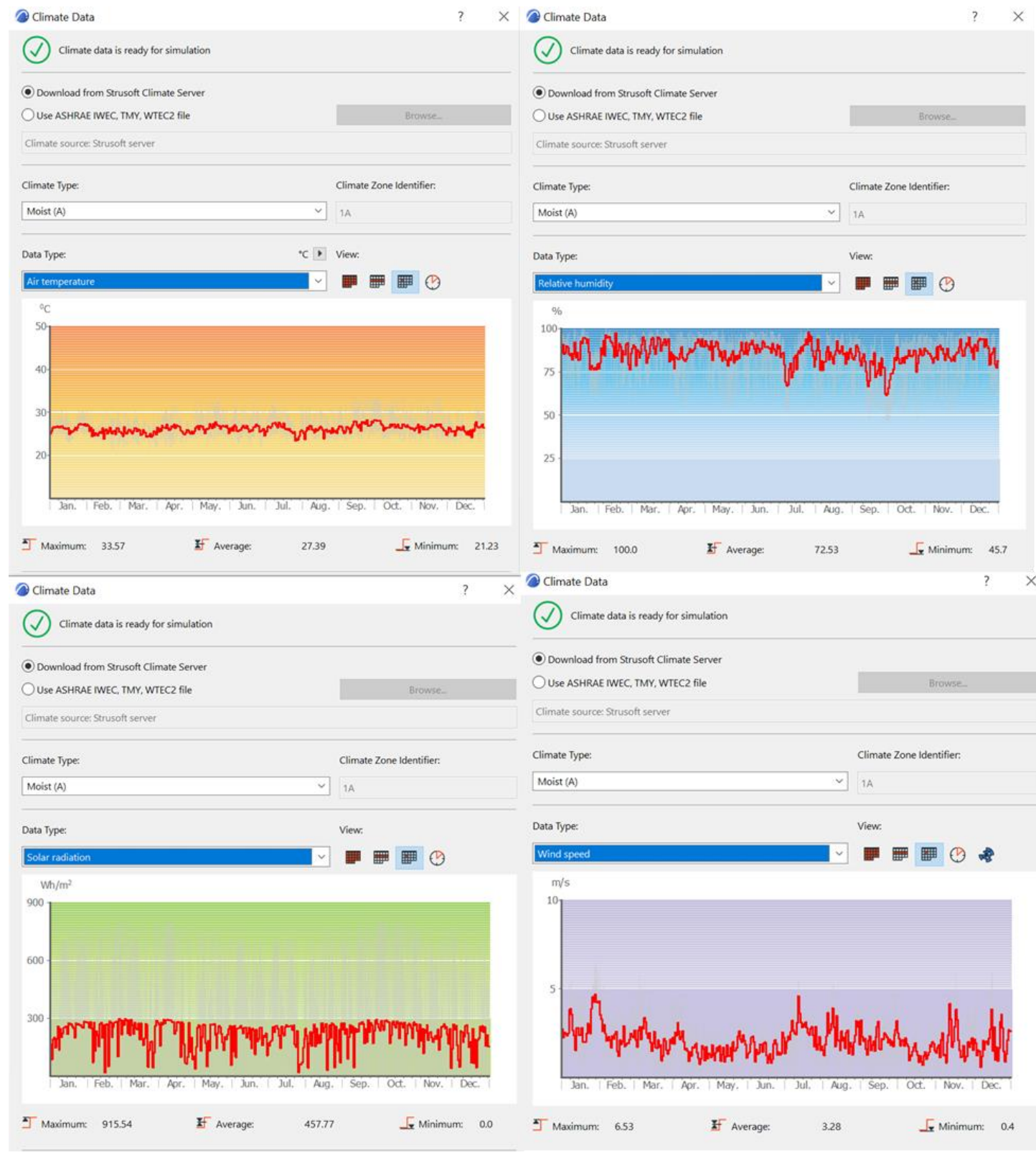

Gambar 4. Data input untuk aspek iklim pada fitur EcoDesigner Sumber. Simulasi, 2020

\section{c. Data dan informasi sistim bangunan}

Sistim bangunan yang digunakan pada gedung yang diteliti mencakup sistim penghawaan udara buatan (AC) yang digunakan sebagai aspek yang dianggap dominan dalam pengunaan energi, khususnya energi listrik. Sistim penghawaan udara buatan (AC) yang digunakan adalah AC Split untuk lantai 1, 2 dan 3 dan AC wall standing untuk lantai 4, 5, 6 dan 7.Untuk AC Split yang digunakan memiliki spesifikasi dengan total daya 51.182 BTU/h, sedangnkan AC wall standing sebesar 54.000 BTU/h. . Berikut gambar tangkapan layar untuk data dan informasi sistim bangunan yang digunakan dalam simulasi evaluasi energi ini 


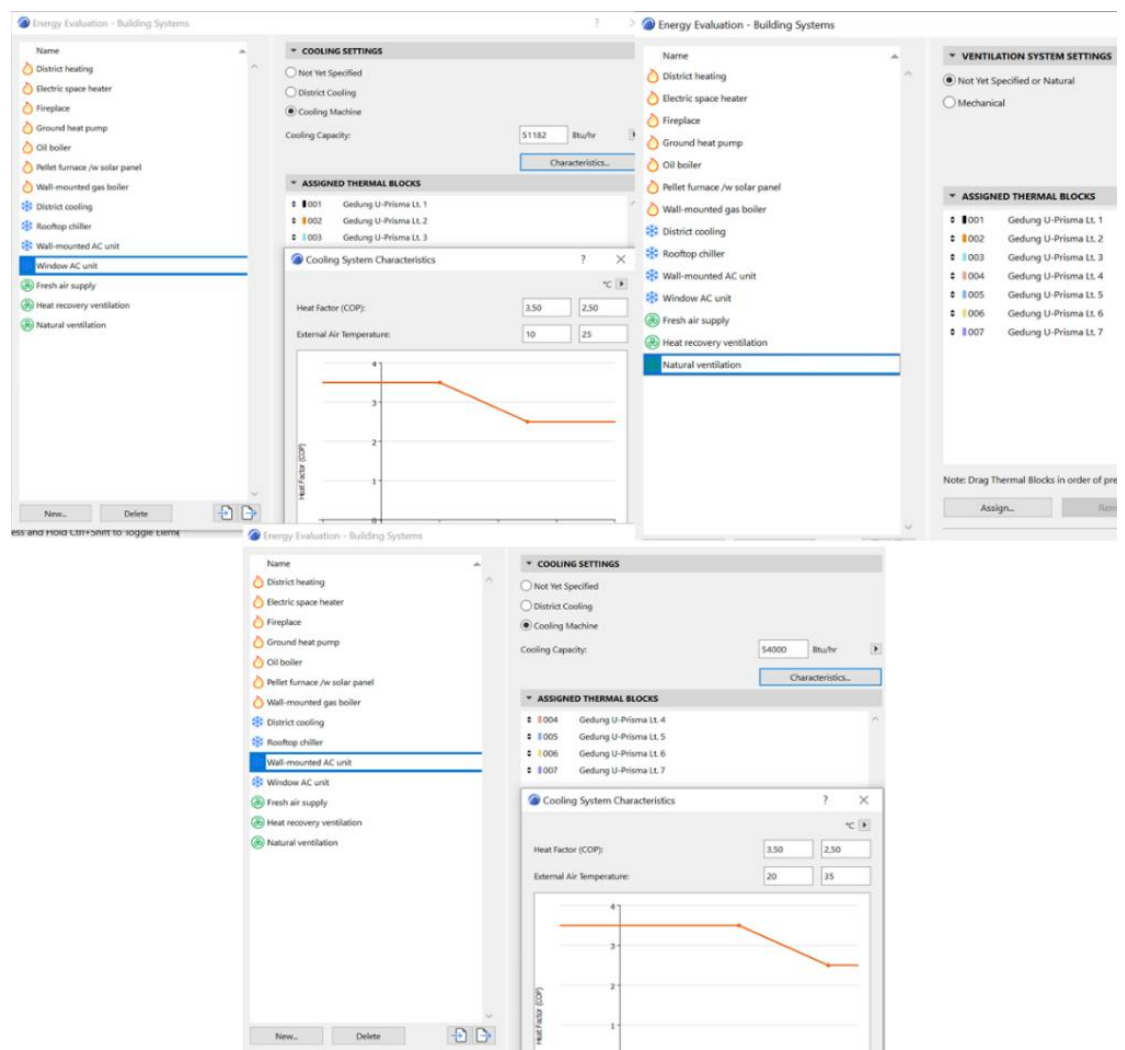

Gambar 5. Data input untuk sistim bangunan (penghawaan alami) pada fitur EcoDesigner Sumber. Simulasi, 2020

\section{d. Data dan informasi profil pengunaan dan spesifikasi ruang}

Sesuai dengan fungsi atau pengunaan ruang dominan pada tiap lantai pada gedung yang di teliti lantai satu adalah untuk kegiatan administrasi dan kantor dengan rata rata 8 jam operasional, internal heat gain 12 $\mathrm{m}^{2} / \mathrm{org}$, suhu rentang $18-28{ }^{\circ} \mathrm{C}$ serta tambahan daya untuk perlengkapan sebesar $0,5 \mathrm{watt} / \mathrm{m}^{2}$. Untuk lantai 2 , 3 4, 5, 6 adalah untuk kegiatan perkuliahan dengan rata-rata 8 jam operasional, internal heat gain $4 \mathrm{~m}^{2} / \mathrm{org}$, suhu rentang $18-28{ }^{\circ} \mathrm{C}$ serta tambahan daya untuk perlengkapan sebesar $0,5 \mathrm{watt} / \mathrm{m}^{2}$. Lantai 7 adalah ruang pertemuan yang hanya digunakan saat tertentu dengan asumsi 2 hari dalam seminggu selama 5 jam operasional. internal heat gain $4 \mathrm{~m}^{2} / \mathrm{org}$, suhu rentang $18-28{ }^{\circ} \mathrm{C}$ serta tambahan daya untuk perlengkapan sebesar $1 \mathrm{watt} / \mathrm{m}^{2}$. Berikut gambar tangkapan layar untuk data dan informasi profil pengunaan ruang yang digunakan dalam simulasi evaluasi energi ini.

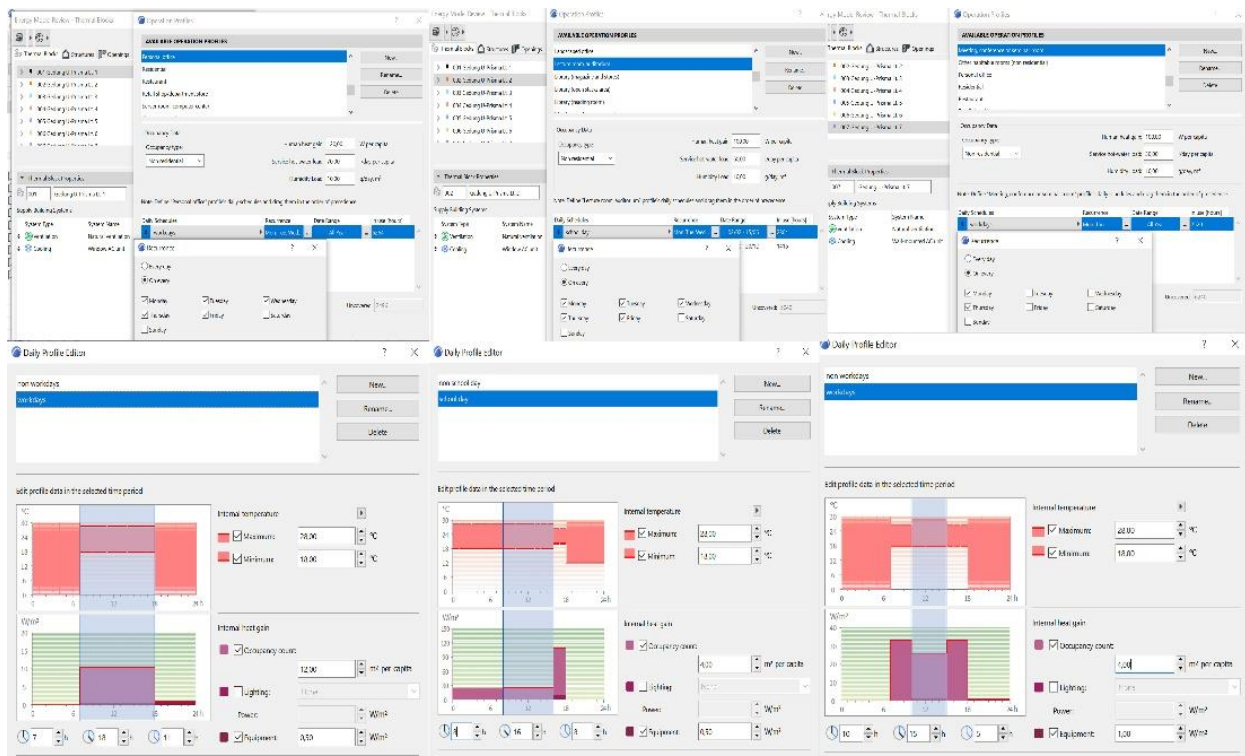

Gambar 6. Data input untuk profil pengunaan dan spesifikasi ruang pada fitur EcoDesigner Sumber. Simulasi, 2020 


\section{e. Data dan informasi sumber energi dan biayanya}

Untuk sumber energi listrik yang digunakan untuk sistim penghawaan udara buatan (AC) bersunber dari listik PLN dengan asumsi pasokan listik untuk Kota Manado adalah dari pembangikt Geotermal sebesar 80\% dan pembangkit Diesel sebesar 20\%. Harga energi listrik didasrkan pada harga harga tarif listrik dasar untuk segmen > 5000 VA sebesar Rp. 1.444,70 /KWh, sedangkan harga solar non subsidi sebesar Rp. 9.400. Berikut gambar tangkapan layar untuk data dan informasi profil sumber energi dan biaya yang digunakan dalam simulasi ini.

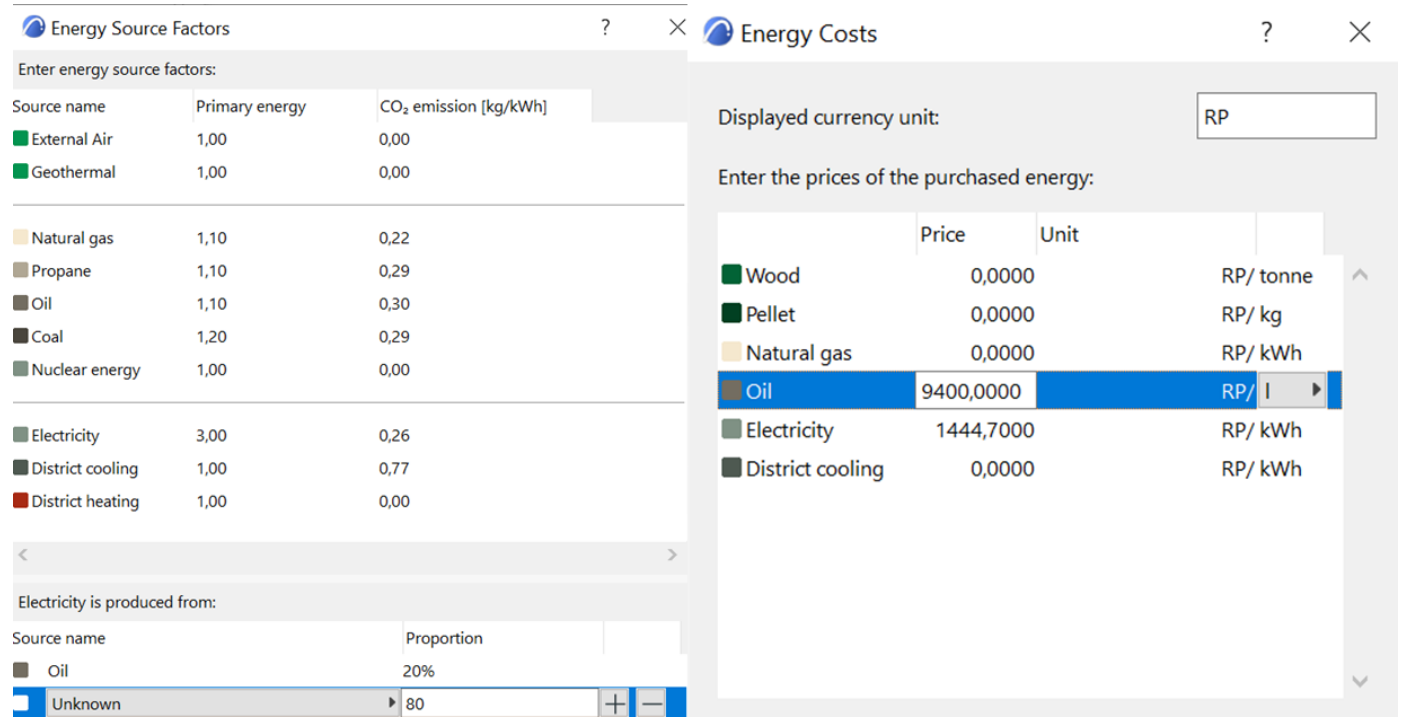

Gambar 7. Data input untuk sumber energi dan biaya pada fitur EcoDesigner Sumber. Simulasi, 2020

\section{f. Hasil simulasi evaluasi energi}

Dari hasil analisis dinamis dan simulasi evaluasi energi pada model bangunan yang telah dibuat termasuk parameter dan kriteria yang dimasukkan berikut output tangkapan layar hasil resume simulasinya :

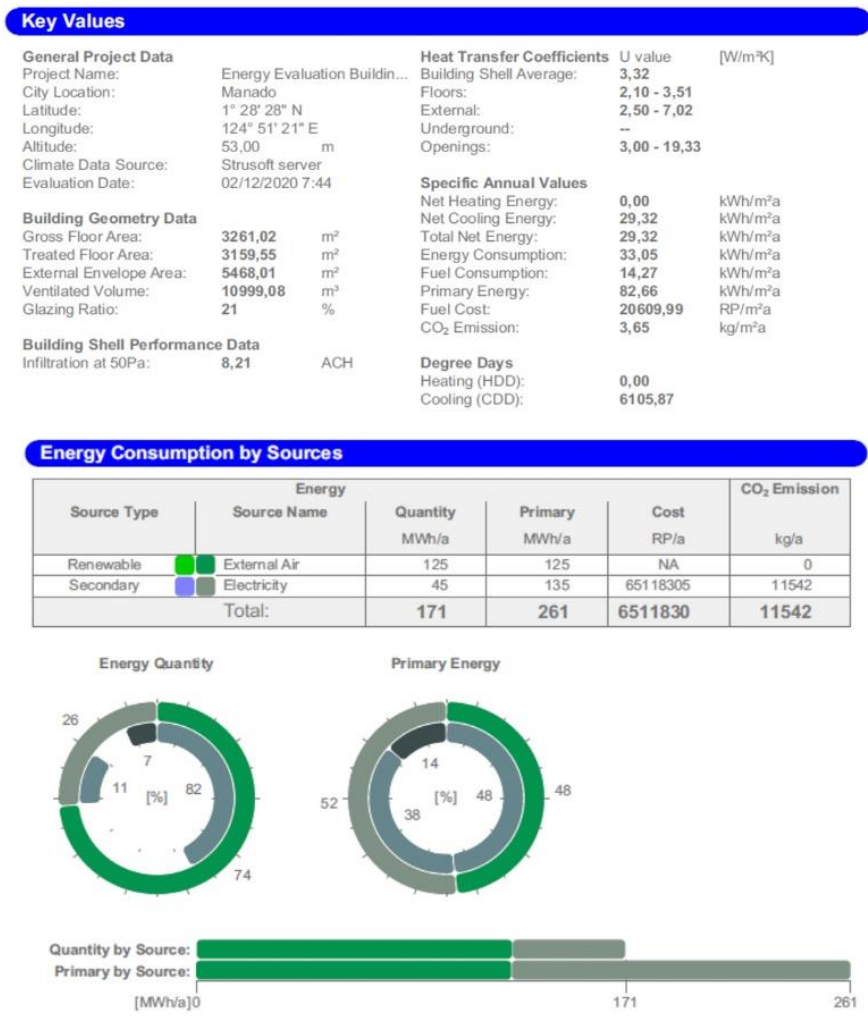

Gambar 8. Hasil simulasi konsumsi energi berdasarkan sumbernya Sumber. Simulasi, 2020 
Berdasarkan simulasi dan perhitungan yang dihasilkan, besar konsumsi energi untuk sistim penghawaan buatan (AC) gedung rata-rata adalah $29,32 \mathrm{KWh} / \mathrm{m}^{2}$. Jika dikonversikan dengan konsunsi bahan bakar maka konsumsi energinya rata-rata adalah $14,27 \mathrm{KWh} \mathrm{KWh} / \mathrm{m}^{2}$, sedangkan jika dikonversikan dengan biaya bahan bakar maka kebutuhan rata-rata nya adalah Rp. 20.610 per $\mathrm{m}^{2}$. Untuk emisi karbondioksida $\left(\mathrm{CO}_{2}\right)$ rata-rata adalah sebesar $3,65 \mathrm{~kg} / \mathrm{m}^{2}$.
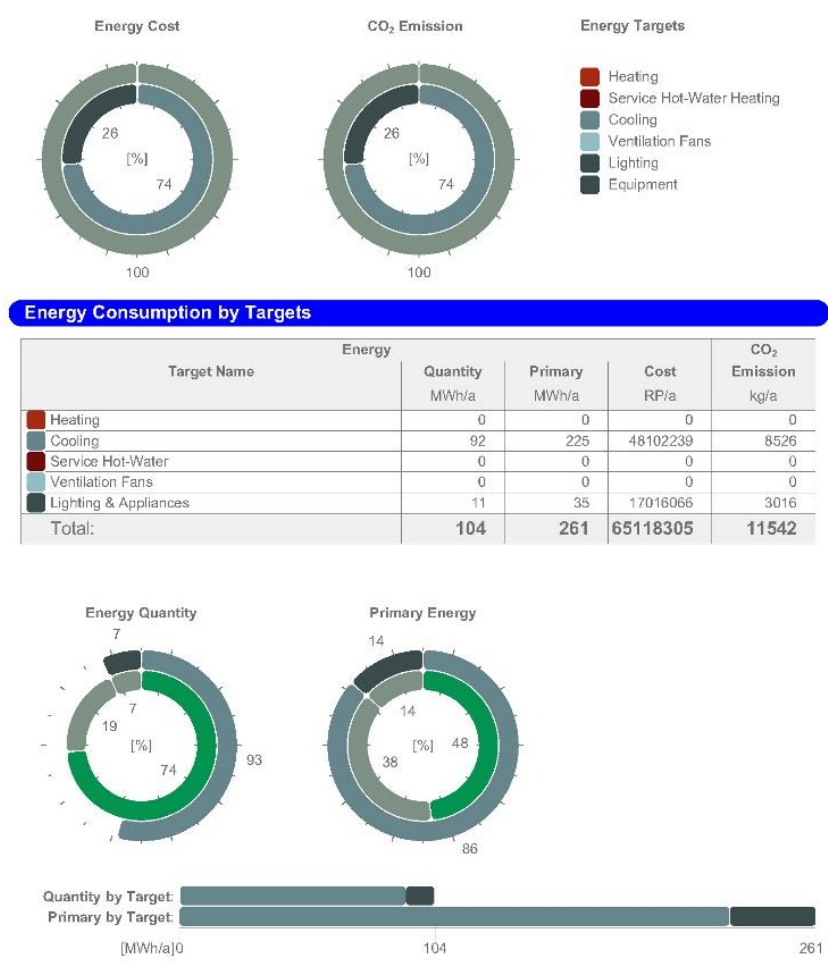

Gambar 9. Hasil simulasi konsumsi energi berdasarkan targetnya

Sumber. Simulasi, 2020

Dari target pengunaan energi pada gedung yang di teliti, hasil simulasi menujukan rata-rata pengunaan utamanya sebesar $261 \mathrm{MWh}$ dari komponen penghawaan udara buatan serta penerangan dan alat listik (sesuai data input profil pengunaan ruang). Estimasi biaya rata-rata yang dibutuhkan per tahun adalah Rp. 65.118.305 dan besar emisi $\mathrm{CO}_{2}$ sebesar $11.542 \mathrm{Kg}$.
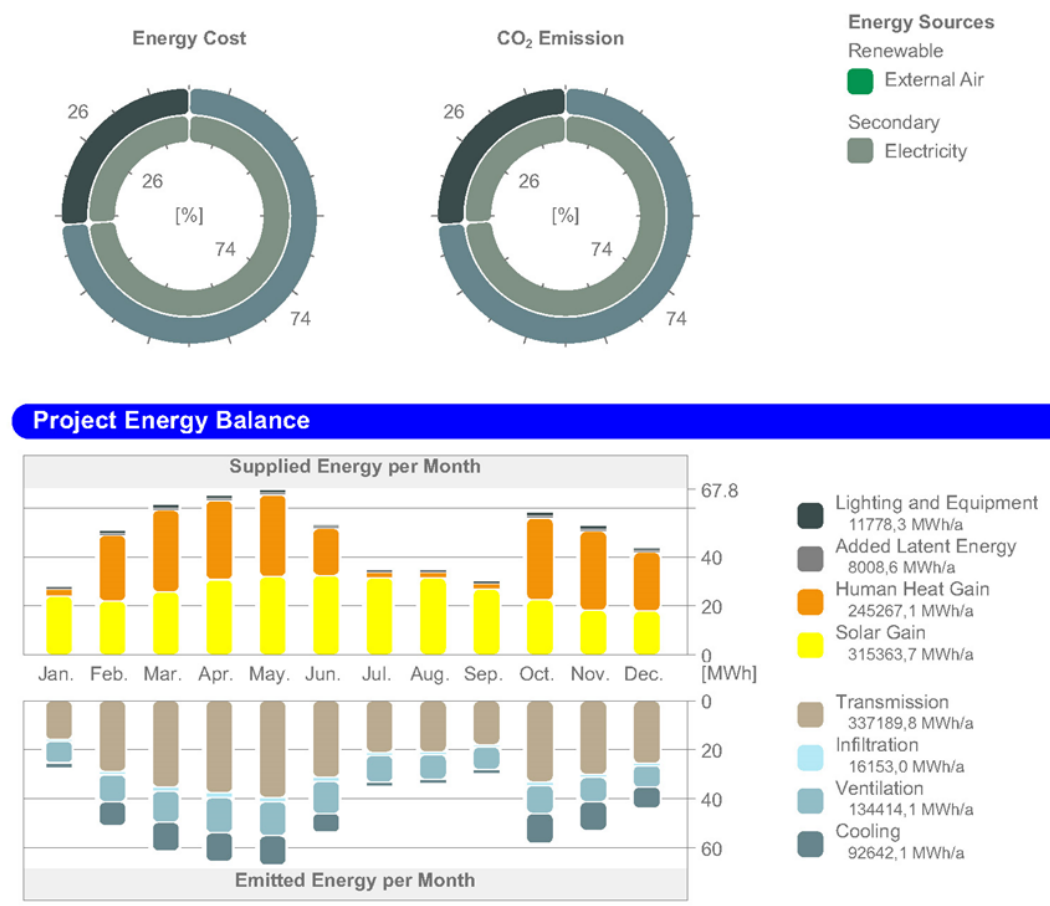

Gambar 10. Hasil simulasi keseimbangan antara energi yang disuplay dan energi yang dikeluarkan Sumber. Simulasi, 2020 
Untuk hasil simulasi keseimbangan energi tersuplai dan yang dikeluarkan, menunjukan porsi terbesar energi tersuplai adalah pada paparan matahari sebesar 315.363,7 MWh dan energi yang diterima adalah pada transmisi energi sebesar 337.189,8 MWh. Untuk energi yang diterima pada aspek penghawaan udara buatan sebesar 92.642,1 MWh.

\section{Kesimpulan}

Dari hasil permodelan kembali gedung yang diteliti dengan mengunakan sofware BIM Archicad R.24 dan simulasi evaluasi energi mengunakan EcoDesigner yang terintegrasi didalamnya, dapat disimpulkan beberapa hal yakni :

a. Model bangunan yang dibuat sudah memiliki informasi spesifikasi material bangunan, yang tersedia dalam sofware, baik dari jenis material fasade utama yang dipilih sesuai spesifikasi gedung yang diteliti (kaca, alumunium komposit panel serta dinding bata yang diplester), maupun dari kinerja material tersebut dalam meredam panas yang sudah terintegrasi dalam data atribut setiap komponen bangunan yang dimodelkan sebagaimana pedoman permodelan software yang digunakan (MacKinzie, 2015)

b. Dengan kemampuan permodelan dan simulasi yang teritegrasi tersebut, memungkinkan diperolehnya gambaran desain bangunan yang kontekstual dan dapat diketahui kinerja atau performa bangunan, khususnya dari aspek pengunaan energi.

c. Unsur selimut bangunan atau fasade serta meterial yang digunakan menjadi salah satu faktor penentu dalam simulasi yang telah dilakukan, dimana dari hasil simulasi telah dilakukan terlah diperoleh pula gambaran performa pengunaan energi, khususnya pada aspek pendinginan udara buatan yang mengunakan energi listrik.

d. Hasil simulasi dari permodelan kembali gedung dengan luas keseluruhan bangunan 3.261,02 $\mathrm{M}^{2}$ dan luas permukaan fasade $5.468,01 \mathrm{M}^{2}$, menunjukan performa fasade dari aspek infiltrasi udara sebesar 8,21 ACH (Air Change per Hour). Hal ini menunjukan walaupun dengan pengunaan penghawaan udara buatan, angka pergantian udara juga masih ideal, mengacu pada standart untuk ruang kuliah atau kantor, yakni sebesar 4-8 ACH (https://www.hvacrschool.com/air-changes-confusion/)

e. Pengunaan energi untuk pengawaan udara buatan (AC) jika di kalkulasikan berdasarkan luas lantai bangunan maka diperoleh $29,32 \mathrm{kWh} / \mathrm{M}^{2}$, atau berada dibawah standart IKE untuk kategori gedung pendidikan sebesar $195 \mathrm{kWh} / \mathrm{M}^{2}$. (USAID Indonesia, 2014)

f. Konsumsi energi listrik untuk penghawaan udara buatan adalah sebesar $29,32 \mathrm{kWh} / \mathrm{M}^{2}$ untuk rata-rata setahun atau sebesar $2,44 \mathrm{kWh} / \mathrm{M}^{2}$ untuk per bulannya. Hal ini masih tergolong sangat efisien sesuai standart pedoman pelaksanaankonservasi energi listrik dan pengawasannya di Lingkungan Departemen Pendidikan Nasional - Teknik Audit Energi Diknas tahun 2006

g. Desain desain fasade yang memiliki glazing ratio sebesar $21 \%$ dan total konsumsi energi 29,32 $\mathrm{kWh} / \mathrm{M}^{2}$, maka jika dibandingkan dengan estimasi jumlah energi listrik dari sistim penghawaan udara buatan pada gedung yang diteliti, sebesar $253.368 \mathrm{KWh}$ rata-rata dalam setahun, dibagi luas bangunan $3261,02 \mathrm{M}^{2}$, maka diperoleh akumulasi konsumsi energi per meter persegi adalah $77,69 \mathrm{kWh} / \mathrm{M}^{2}$. Hal ini melampaui hasil simulasi yakni sebesar $37,73 \%$. Hal ini menunjukan masih dimungkinkannya potensi pengehematan energi khususnya dari aspek pengunaan energi untuk sistim penghawaan udara buatan, yakni sebesar Rp. 11.511.021 per tahunnya (Mukhlis, 2011)

h. Dengan rasio bidang kaca sebesar $21 \%$, konskuensi terpaan panas matahari rata-rata dalam setahun adalah sebesar 315.363, $7 \mathrm{MWh}$, untuk energi yang di keluarkan dari aspek pendinginan udara buatan adalah sebesar 92.642,1 MWh, atau sebesar 29,37\% yang diterima. Hal ini menunjukan semakin besar rasio bidang kaca semakin besar pula energi yang dibutuhkan untuk aspek pendinginan udara buatan. Berdasarkan beberapa kesimpulan diatas penelitian ini telah diperoleh gambaran yang jelas tentang evaluasi energi pada gedung sudah terbangun dan beroperasi, dimana desain fasade suatu bagunan baik dari konfigurasi bentuk dan tampilan, penempatan pada tapak, situasi sekitar tapak, karakteristik iklim, pemilihan material serta rasio bidang kaca, memiliki pengaruh yang kuat dalam pengunaan energi serta upaya untuk konservasinya.

\section{Referensi}

Allen, Edward. (2005). Dasar-dasar Konstruksi Bangunan Bahan-bahan dan Metodenya. Jakarta: Penerbit Erlangga. 
Chae, Heegeon. (2017). Architectural visualization of a BIM-based model 3D modelling and visualization. Helsinki: Metropolia University.

Sacks, Rafael., E, Chuck., Lee, G. , Teicholz, P. (2018). BIM (Building Information Modeling) Handbook $3^{\text {rd }}$ Edition. New Jersey: John Wiley\& Sons Press.

Graphisoft. (2014) EcoDesigner Star User Manual, from http://www.graphisoft.com

Kusumawati, Lili., Lahji, Khotijah. (2015) Pengaruh Disain Fasade Terhadap Efisiensi Energi. Disampaikan pada Seminar Nasional Keberlanjutan Ruang Huni Masa Depan EKO-ARSITEKTUR, Jurusan Arsitektur, FTSP, Universitas Trisakti, Jakarta.

MacKinzie, Scott H, Rendek, Adam. (2015) ArchiCAD 19 - The Definitive Guide. Birmingham : Packt publishing.

Mukhlis, Baso (2011). Evaluasi Penggunaan Listrik Pada Bangunan Gedung di Lingkungan Universitas Tadulako. Jurnal Ilmiah Foristek Vol.1, No. 1, Maret 2011

Rosman, Ahmad, (2007). Bahan Bangunan Sebagai Dasar Pengetahuan. Jakarta: Penerbit Bangun Cipta.

Sebestyen. Gyula. (2003). New Architecture and Technology. New York: Architectural Press.

Tymkow, Paul., Tassou, S.., Kolokotroni, M.,. Jouhara, H.. (2013). Building Services Design for Energy Efficient Buildings, New York: Routlegde Press.

USAID Indonesia (2014). Panduan pengematan energi di gedung pemerintah sesuai amanat Peraturan Menteri ESDM No. 13 tahun 2012 tentang penghematan energi listrik, Panduan penghematan energi di gedung pemerintah sesuai amanat Peraturan Menteri ESDM No. 13 tahun 2012 tentang penghematan pemakaian listrik, USAID Indonesia Clean Energy Development (ICED Project. www.iced.or.id. 